\title{
Access and allocation in climate change adaptation
}

\author{
Kevin Grecksch ${ }^{1}$ (D) . Carola Klöck ${ }^{2}$ (D)
}

Accepted: 3 April 2020 / Published online: 19 April 2020

(c) The Author(s) 2020

\begin{abstract}
As climate change impacts become increasingly apparent, adaptation becomes increasingly urgent. Accordingly, adaptation to climate change has shifted towards the centre of attention in both policy and research. In this article, we review the last 10 years of adaptation research (2008-2018), with a focus on work within the Earth System Governance network. We use the lens of access and allocation to structure our review and examine how adaptation affects, and is affected by, access to basic needs, basic rights, and decision-making on the one hand, as well as allocation of responsibilities, resources, and risks on the other. We find that questions of justice, equity, and fairness are fundamental to all dimensions of adaptation. The access perspective, for example, suggests that we need to assess vulnerability, understood broadly, while the allocation perspective focuses on questions of responsibility for being vulnerable, e.g. when people live, or move to, hazard-prone areas exposed to climate risk. This also relates to questions of who is responsible for selecting, implementing, and funding adaptation measures. Overall, we find that the framework of "access and allocation" and its subcategories offer a detailed approach to adaptation and adaptation research, but that it is not intuitive. The notion of "climate justice" seems to resonate more with both academic and policy debates.
\end{abstract}

Keywords Access and allocation · Climate change adaptation - Earth System Governance · Climate justice

\section{Introduction}

As climate change impacts become more and more apparent, adaptation has become urgent. Impacts abound and vary; they include sea-level rise, increased temperatures, changing precipitation patterns and increased frequency of extreme weather events such as droughts or floods. Impacts may result, among many others, in displacement, decreases in livelihoods, or health impacts such as the spread of vector-borne diseases (IPCC 2018).

Kevin Grecksch

kevin.grecksch@csls.ox.ac.uk

Carola Klöck

carola.kloeck@sciencespo.fr

1 Centre for Socio-Legal Studies, University of Oxford, Manor Road, Oxford OX1 3UQ, UK

2 Centre for International Research (CERI), Sciences Po Paris, 56 rue Jacob, 75006 Paris, France 
Adaptation, at the most general level, is the "process of adjustment to actual or expected climate and its effects" (IPCC 2013: 1758). This adjustment "presents formidable dilemmas of justice to the international community, ones which are more complex and no less important to those presented by mitigation" (Paavola and Adger 2006: 594; see also, e.g. Schroeder 2014). Nonetheless, as compared to mitigation, adaptation has long been neglected in policy and academic debates. Yet, it has become increasingly clear that we are not mitigating enough to prevent climate change. For instance, man-made emissions from burning fossil fuels, building infrastructure, growing crops and transporting goods meant that 2019 was set to break the record for atmospheric carbon concentrations, locking in further warming (WMO 2019). Accordingly, adaptation has grown in political and scholarly relevance, as indicated, for example, by the creation of the Adaptation Fund, the global "adaptation goal" in the Paris Agreement (UNFCCC 2015), or the growing adaptation literature (e.g. Bassett and Fogelman 2013).

In line with this growing relevance, it is timely to take stock of adaptation research within Earth System Governance (ESG) as the largest social science research network in the area of global environmental change and governance. We focus specifically on how access and allocation are understood in the area of climate adaptation governance within the ESG literature of the last 10 years (2008-2018). In Sect. 2, we first introduce the access and allocation component of the ESG Research Framework and explain our approach. We then turn to the issues of access as well as of allocation that are discussed in ESG adaptation research in Sects. 3 and 4, respectively. In the final section, we reflect on the findings from our review and highlight that while issues around justice, equity, inequality, or fairness are central to adaptation research, these questions are rarely discussed under the terms "access and allocation".

\section{Access and allocation in Earth System Governance}

The 2009 ESG research framework includes questions of justice, fairness, and equity under the rubric "access and allocation", one of the key problems in ESG (Biermann et al. 2009). Access and allocation refer to distributional issues and to the ways in which governance deals with questions of equity (Bastos Lima and Gupta 2013: 48f); as such, questions of access and allocation are inherent in climate change adaptation. Yet, different disciplines have articulated and framed access and allocation in different ways. The multidisciplinary governance framework of Gupta and Lebel (2010) integrates these approaches to access and allocation. In the context of climate change, the authors define access "in terms of access to minimum resources and ecospace (the per capita minimum right to emit greenhouse gases) and access to security (that is, that basic human rights are not jeopardised by the impacts of climate change)" (Gupta and Lebel 2010: 386). To this understanding of access primarily in material terms, Bastos Lima and Gupta (2013) add a more abstract level and understand access also as participation in decision-making. This corresponds to the element of access to social processes, i.e. access to social movements and systems of justice raised by Gupta and Lebel (2010). Access thus is also a question of who gets to define issues of responsibility, equity, and justice, as well as who participates and is represented (Bulkeley and Newell 2010; Holland 2017). Accordingly, we understand access in terms of (1) basic needs; (2) basic rights; and (3) decision-making.

Allocation looks at how the remainder of resources can best be divided among people and countries. More specifically, allocation has three dimensions: it concerns the 
distribution of (1) resources, benefits, and opportunities; (2) responsibilities; and (3) risks and burdens (Biermann et al. 2009: 48; Gupta and Lebel 2010: 379; Bastos Lima and Gupta 2013). We make use of this multidimensional framework of access and allocation to structure our literature review (Sects. 3 and 4).

The adaptation literature is vast and growing quickly; a comprehensive overview of this body of work is daunting. In line with this special issue, we here focus primarily on research by the ESG community. ESG is a global research alliance and the largest social science research network in the area of global environmental changes and governance. The aim of this special issue is, as explained elsewhere, to harvest lessons learnt from 10 years of ESG research. We started with research that explicitly uses the ESG terminology and examines access and allocation, compiled in a literature database by the ESG project containing 261 entries, of which 35 were classified as pertaining to access and allocation. We extended this database by including related adaptation research, primarily from our own research in the area, and reviewed a total of over 200 articles and chapters. As the next section shows, even this limited scope and ESG focus provide a wealth of insights on the status of adaptation research. The review follows a nonsystematic approach and therefore does not claim to be fully comprehensive. Yet, given its multidisciplinary nature, a focus on ESG means we are able to review a large variety of publications. We are thus confident that we cover a wide range of social science research related to "access and allocation", that is, justice, equity, and fairness, in the context of climate change adaptation.

\section{Access}

Put simply, access describes the right or opportunity to use or benefit from something, for example resources. In the following, we discuss access as access to basic needs (Sect. 3.1); to basic rights (Sect. 3.2); and to decision-making (Sect. 3.3).

\subsection{Access to basic needs}

A large strand of adaptation research has focused on assessing vulnerability as a precondition for understanding adaptation needs (Grothmann et al. 2013; de Sherbinin et al. 2019; Woroniecki et al. 2019). In the terminology of the ESG framework, this research has been interested in how climate change affects basic needs, as well as how adaptation can minimize adverse effects of climate change and safeguard access to basic needs.

Vulnerability reflects the extent to which access to basic needs is affected. Yet, vulnerability is far from being clearly defined. At the most general level, it can be understood as "the capacity to be harmed" (Moss et al. 2001: 2), or "the propensity or predisposition to be adversely affected" (IPCC 2014). Much research has understood this capacity or propensity in terms of exposure to hazards and risks and accordingly focused on technical solutions. This hazards approach has been criticised, and the notion of vulnerability expanded (Bassett and Fogelman 2013; Barrowman and Kumar 2018; Mikulewicz 2018).

More and more scholars focus instead on underlying socio-economic drivers of vulnerability (Mikulewicz 2018) as well as on adaptive capacity (Siders 2019). This social vulnerability approach emphasises the links between vulnerability and governance (see also Biermann et al. 2009) and calls for a broader understanding of adaptation as a political process (Eriksen et al. 2015; Klepp and Chavez-Rodriguez 2018). Vulnerability, from this perspective, is not an intrinsic, measurable condition. Vulnerability is produced, constructed, 
"performed" (Webber 2015). Being about risks and about which risks are acceptable to a society, vulnerability is inherently subjective, normative, and political (Klein 2009; Scoville-Simonds et al. 2020) and therefore cannot be measured (Eriksen and Kelly 2007: 500). Further, vulnerability is specific to a risk, and not a generic condition (Barnett and Campbell 2010), and varies even within small communities. For example, women or the poor are typically more vulnerable than men or richer community members (Dulal et al. 2009; Buggy and McNamara 2016). These aspects of adaptation add to the difficulties of vulnerability assessments and measurements and point to the need for paying attention to community-internal differences as well as the power dynamics that influence adaptation decisionmaking (see Sect. 3.3) and implementation on the ground (Nightingale 2017; Thomas and Warner 2019; Scoville-Simonds et al. 2020).

\subsection{Access to basic rights}

Climate change also threatens basic, or human, rights, which are of course closely related to basic needs. No violation of human rights should occur because of global environmental problems (Gupta and Lebel 2010), yet many rights, such as "the right to security in the event of [...] lack of livelihood in circumstances beyond his control" (United Nations 1948: Art. 25.1) could potentially be affected by climate change.

The adaptation literature tends to focus on climate-induced migration and displacement when speaking about (human) rights (Warner 2010; Berchin et al. 2017; IOM 2018). Climate change impacts such as sea-level rise or droughts interact with other anthropogenic pressures and can thus contribute to migration and displacement. Relocation, displacement, and migration have received most academic attention in the context of sea-level rise in lowlying coastal areas as well as drought, with a geographic focus on the Global South (Mortreux and Barnett 2009; Campbell 2014; Marino and Lazrus 2015; Gharbaoui and Blocher 2016; Piguet et al. 2018; Cvitanovic et al. 2019). Forced displacement, both relocation and migration, clearly affects access: loss of land and home, and therefore potentially loss of culture and identity is a serious human rights violation.

How can human rights be safeguarded in such contexts? To what extent do displaced people qualify as "climate refugees"? A growing literature addresses these questions (Piguet et al. 2011; Bose and Lunstrum 2014; Berchin et al. 2017). More recently, discussions have also turned to cases where affected populations may want to migrate but are unable to do so, so-called trapped populations (Foresight 2011; Ayeb-Karlsson et al. 2018; Nawrotzki and DeWaard 2018), as well as cases where affected populations decide to stay despite the potential harm from climate impacts, so-called voluntary immobility (Farbotko et al. 2018; Zickgraf 2018). Migration and displacement also have implications for allocation, notably the question of who pays-or should pay-for relocation (see Sect. 4.2). Finally, the intangible implications of displacement, such as loss of culture and identity and notions of "ontological security" (Kinnvall and Mitzen 2017; Farbotko 2019; Farbotko and McMichael 2019), have received increased scholarly attention.

Discussions of rights in the context of climate change adaptation also concern the issue of loss and damage: cases where adaptation is no longer possible, or where it has failed. A detailed discussion of loss and damage is beyond the scope of this review (for overviews, see McNamara and Jackson 2019; Mechler et al. 2019). Suffice it to say that many of the questions around loss and damage mirror those related to displacement and migration, notably those around loss of culture and identity and "ontological security". 


\subsection{Access to decision-making}

A third dimension of access that is not part of the original ESG Research Framework but that some authors subsume under the notion of access relates to participation in decision-making (Bastos Lima and Gupta 2013). Access thus is also a question of who gets to define issues of responsibility, equity, and justice, and who participates and is represented (Bulkeley and Newell 2010; Holland 2017). Access to decision-making around adaptation is highly uneven, at all levels (Scoville-Simonds et al. 2020). We here focus on decision-making at the local level and at the international level, as these two levels are central to adaptation.

Much research agrees that adaptation occurs at the local or community level and that local-level institutions are therefore important determinants of adaptation success (Dulal et al. 2009; Fenton et al. 2014). Community-based adaptation (CbA) has been promoted in the context of developing countries as a tool for development partners and local stakeholders to come together and jointly address climate change (e.g. Reid et al. 2009; Schipper et al. 2014; Kirkby et al. 2018), but the opportunities and risks of CbA also apply in developed country contexts (e.g. Hayward 2008). CbA holds many promises; it emphasises local ownership, reflects local priorities, and seeks to integrate local knowledge, all of which have been identified as key factors for adaptation success (e.g. Barnett 2008: 45; Granderson 2014; McNamara and Combes 2015). At the same time, $\mathrm{CbA}$ also has pitfalls. Notably, awareness and understanding of climate science is least prevalent at the local level, in both developing (Lata and Nunn 2012; Nunn et al. 2014; Betzold 2015) and developed (Capstick et al. 2015) country contexts. Further, neither practice nor research has paid sufficient attention to what and who the community is, and how power relations play out at this local level (Buggy and McNamara 2016; see also Sect. 3.1).

Only recently, critical adaptation research has focused on these political aspects of adaptation and explicitly understands adaptation as a political process (see Sect. 3.1), where some participants will lose and others will benefit from adaptation. Decisionmaking on adaptation reflects power constellations and does not always include all affected stakeholders. Participatory processes and $\mathrm{CbA}$ may hence potentially reinforce, rather than reduce, inequities and power imbalances (Eriksen et al. 2015; Buggy and McNamara 2016; Nightingale 2017; Ensor et al. 2018; Mikulewicz 2018). This violates the principle of procedural justice (Coolsaet and Pitseys 2015). Research into climate change adaptation must take into account power and procedural justice, i.e. examine who is involved in decision-making, whose voices(s) are heard-as well as whose voices(s) are not heard, at all levels (Scoville-Simonds et al. 2020).

Similar concerns about procedural justice apply at the global level, where negotiations on climate change reflect global inequalities, notably between the Global North and the Global South. Negotiations under the United Nations Framework Convention on Climate Change (UNFCCC) are the main forum in which adaptation and adaptation finance are negotiated and governed. However, the negotiations are not a level playing field; smaller and poorer countries are at a disadvantage because of unequal access, different delegation sizes, and differences in expertise and language skills (cf. Chasek and Rajaman 2003; Paavola and Adger 2006; Bulkeley and Newell 2010; Schroeder et al. 2012; Roberts and Parks 2014; Coolsaet and Pitseys 2015). The late arrival of adaptation onto the negotiation agenda reflects these power inequalities: adaptation was long considered a "developing country issue" that powerful industrialised countries could 
keep off the agenda, not least for fears of attribution of responsibility and claims for compensation (Schipper 2006). The UNFCCC process as an intergovernmental forum also privileges the access of national government actors, at the expense of nonstate actors or subnational unities, including indigenous peoples (Schroeder and Lovell 2012; Betzold and Flesken 2014). Although these actors are key stakeholders and often play important roles in local-level adaptation, their "participation access"(Jinnah 2014) at the international level is limited.

\section{Allocation}

Allocation plays an important role in adaptation research. One area of research focuses on the cost of adaptation and the distribution of resources (Sect. 4.1). This question of allocating resources relates to the question of responsibility for climate change, as well as for vulnerability to its impacts (Sect. 4.2). Finally, research has also focused on the risks and benefits of adaptation itself (Sect. 4.3).

\subsection{Allocation of resources}

A large strand of the literature focuses on assessing the costs of adaptation, with estimates ranging from $\$ 4$ billion to over $\$ 100$ billion per year (Narain et al. 2011; Weikmans 2012). While it is impossible to put a price tag on adaptation needs, it is clear that making the world climate-resilient requires significant funding. Accordingly, both governments and private actors invest significantly in adaptation measures (Buchner et al. 2017). In poorer countries, however, adaptation often depends on the availability of external support (Habtezion et al. 2015) — not least due to the "adaptation deficit", that is, the lack of preparedness even to current climate variability and extremes (Burton 2004; Fankhauser and McDermott 2014).

International assistance for climate change adaptation plays a central role in the global climate negotiations, notably since the 2009 pledge to "mobilise" US $\$ 100$ billion annually from 2020 onwards, for both mitigation and adaptation. This funding should be "new and additional" (UNFCCC 2009), but a baseline compared to which finance should be additional has not been defined. Similarly, there is no clear definition of what adaptation is (Stadelmann et al. 2011; Robert and Weikmans 2017). What counts towards the $\$ 100$ billion target, who should contribute how much, or how finance flows should be measured and tracked in general is equally contested (Ayers and Huq 2009; Ayers and Dodman 2010; Khan and Roberts 2013; Dasgupta and Climate Finance Unit 2015; Weikmans and Robert 2017). From a justice perspective, it is important that these questions be addressed, as only predictable and accessible finance that does not come at the expense of other development projects can meaningfully help recipients deal with growing climate impacts. However, who these recipients should be is also controversial, despite the political and academic consensus of prioritising the most vulnerable (Grasso 2010a, b; Ciplet et al. 2013; Duus-Otterström 2015). Yet, as discussed in Sect. 3.1, identifying the most vulnerable is problematic. It may thus come as no surprise that empirical analyses of adaptation finance distribution find only limited evidence that donors allocate adaptation finance to vulnerable countries or communities (Remling and Persson 2015; Robertsen et al. 2015; Betzold and Weiler 2016; Robinson and Dornan 2017; Weiler et al. 2018). For the subnational allocation of adaptation finance in Malawi, Barrett (2014: 131) even concludes that "[t]he 
poorest, most marginalized, and climate vulnerable districts receive the least adaptation finance" (see also Barrett 2015).

In the long run, international climate finance may decrease, as adaptation within donor countries requires increasing amounts of finance (Nunn and Kumar 2019). To understand when, where, and how adaptation occurs, it is thus necessary to also consider nonmaterial resources. Research has highlighted the numerous cultural, social, and governance dimensions of adaptive capacity, beyond just financial and technical resources (Nielsen and Reenberg 2010; Eakin et al. 2014; Siders 2019). In particular, risk perceptions, as well as political dynamics, influence when and how resources (of all types) are mobilised and used for adaptation (Granderson 2014).

\subsection{Allocation of responsibilities}

Allocation also concerns responsibilities: Who is responsible for taking adaptation decision, implementing them, and paying for them? To answer this question, we also need to think about the responsibility for climate change impacts, and for vulnerability to these impacts.

There is consensus that the costs of adaptation should not only fall upon those affected by climate change (Hartzell-Nichols 2011), as those most affected tend to have contributed the least to global greenhouse gas emissions. The question of responsibility for climate change has been discussed elsewhere (Ringius et al. 2002; Kanie et al. 2010; Underdal and Wei 2015), also with regard to its implications for adaptation finance (Dellink et al. 2009; Cui and Gui 2015; Khan 2015; Pickering et al. 2015; Cui and Huang 2018).

The question of allocating responsibility also has a second dimension: Who is responsible for vulnerability to climate change impacts? As discussed in Sect. 3.1, vulnerability is place and context specific and is closely related to socio-economic, institutional, political, and cultural factors. Poorly governed countries, for example, have less adaptive capacity and as such are more vulnerable, but one may ask "whether the population in the country with poor governance should be regarded primarily as vulnerable or also as (partly) responsible for its vulnerability" (Füssel 2009, pp. 18-19). Similar questions can be raised with regard to sensitivity: for example, who is responsible when people move to dangerous places, such as substandard housing in flood-prone slums (Weber et al. 2019)?

These questions of attribution of responsibility for implementing and financing adaptation also relate to the distinction between public and private adaptation. The former, sometimes also referred to as planned adaptation, is adaptation carried out by government (at all levels). In contrast, private, or autonomous, adaptation is carried out by the private sector, households, or individuals (Schneider 2014; Rotter et al. 2016; Goldstein et al. 2019). These two are interlinked. Public adaptation may support and promote private adaptation, for example through policies and regulation (Mees et al. 2013; Biesbroek et al. 2018), but also shift responsibility to private actors (Nalau et al. 2015). Often, however, the public sector is expected to become active. Particularly in poorer countries, the public sector may not function well, such that responsibility or the "burden of adaptation" (Eakin et al. 2014) is transferred to private actors, who may or may not have the necessary resources (Sheller and León 2016; Juhola 2019; see also Sect. 3.1). Finally, adaptation is often understood as a local issue; local government and local institutions hence play a crucial role in enabling — or hindering — adaptation (Dulal et al. 2009; Grecksch 2013; Fenton et al. 2014; Grecksch 2015). At the same time, adaptation finance and adaptation policies and plans are often located at the national level (Fenton et al. 2014; Massey et al. 2014; Habtezion et al. 
2015). The literature hence discusses to what extent adaptation is, or should be, indeed local (Nalau et al. 2015; Juhola 2019).

\subsection{Allocation of risks}

Finally, discussions of allocation also revolve around the allocation of risks and benefits of adaptation itself: adaptation does not only protect from (climate) risks, but may also create risks itself.

A growing body of research focuses on evaluating to what extent adaptation is successful. However, defining "adaptation success" is contested (Doria de França et al. 2009; Dilling et al. 2019). At the broadest level, successful adaptation meets its objectivesreducing vulnerability and/or increasing adaptive capacity. Yet, evaluation against these objectives is not enough, as adaptation may produce externalities at other spatial and temporal scales: an action may be effective for one actor, but not for another, or may be effective in the short but not the long run (Adger et al. 2005; McEvoy and Wilder 2012). Scholars have therefore focused on generic principles of policy appraisal and understood "successful" adaptation as adaptation that is effective, efficient, and equitable (Adger et al. 2005; Stern 2008). Some add flexibility as a central characteristic of successful adaptation: successful adaptation must be able to respond to changes in environmental conditions and in scientific knowledge and thus avoid path dependency (Magnan 2014).

In line with these generic principles, adaptation research has identified generic success factors and barriers. Success is mainly linked to local ownership and participation (see Sect. 3.3), which integrates local and indigenous knowledge and enables holistic and culturally appropriate solutions (Patt and Schröter 2008; Ford et al. 2016; Flynn et al. 2018; Klöck and Nunn 2019). In contrast, generic barriers to adaptation include cognitive and cultural barriers (e.g. lack of awareness, misperceptions of climate change, uncertainty), resource barriers (e.g. limited finance), and institutional barriers (e.g. no enforcement of regulations, fragmentation) (Nielsen and Reenberg 2010; Eisenack et al. 2014; Kuruppu and Willie 2014; Betzold 2015; Oberlack 2017). Nonetheless, evaluation of concrete adaptation actions is rare, due to the lack of clear definitions and metrics of adaptation success (Stadelmann et al. 2014). Several studies of specific adaptation projects also explicitly argue that it is too early for an assessment of success (Patt and Schröter 2008; Dumaru 2010).

The opposite of successful adaptation is mal-adaptation: "action taken ostensibly to avoid or reduce vulnerability to climate change that impacts adversely on, or increases the vulnerability of other systems, sectors or social groups"(Barnett and O'Neill 2010: 211; Juhola et al. 2016). There is some evidence that reliance on donor-funding may reduce adaptation effectiveness (Barnett 2008; Betzold 2015) or that certain measures are maladaptive. This is notably the case for "hard" or infrastructural projects, such as seawalls and other coastal defence measures to counter coastal erosion and flooding, which are popular yet often increase and/or displace erosion (Cooper and Pilkey 2012; Nunn 2013; Betzold and Mohamed 2017). Adaptation itself produces winners and losers (Eriksen et al. 2015; Nightingale 2017: 12; Winges and Grecksch 2017; Mikulewicz 2018; Siebenhüner 2018), yet these distributional effects of adaptation measures have been rarely studied (Gibbs 2016). Adaptation may reproduce and even deepen underlying inequalities and social vulnerability, by favouring the wealthier and more powerful, for example in Nepal (Nightingale 2017), Kenya and Malawi (Barrett 2014, 2015), and beyond (Thomas and Warner 2019). Research has slowly started to include power politics into adaptation analysis and 
suggests that the choice of adaptation options depends on access to decision-making (see Sect. 3.3).

\section{Conclusion}

As climate change impacts become increasingly apparent, adaptation becomes increasingly urgent. Accordingly, adaptation to climate change has shifted towards the centre of attention in both policy and research. We here reviewed the adaptation literature with a focus on ESG research and through the lens of access and allocation. Specifically, we examined how adaptation affects, and is affected by, access to basic needs, basic rights, and decisionmaking on the one hand, as well as allocation of responsibilities, resources, and risks on the other.

The access perspective to adaptation requires in particular assessing vulnerability, which needs to be understood and studied broadly, beyond a narrow focus on climate risks. Socioeconomic and political factors also contribute to vulnerability, and climate change cannot be isolated from these underlying drivers of vulnerability. Adaptive capacity, a key constituent of vulnerability, is especially contested because it comprises too many dimensions. Thus, a common and basic understanding of what adaptive capacity means and entails is necessary. It has also become clear that a violation of basic rights leads and could lead to further migration and displacement, yet some people may also be unwilling or unable to move, or by migrating become even more vulnerable. Climate change also threatens identity and culture. We found that climate adaptation is a political process involving power as key component leaving us with the central question of who is involved and who can participate. International climate change negotiations are still not at level playing field. A focus on access to decision-making processes is thus needed to better understand who adapts, how, when, and to what impacts — and similarly, where adaptation does not occur.

The allocation perspective to adaptation complements this access perspective. A broader understanding of vulnerability and a political understanding of adaptation go hand in hand with assessing responsibility for being vulnerable (e.g. living in hazard-prone areas exposed to climate risks), for selecting, implementing, and funding adaptation measuresand for creating potential negative side effects. The issue of adaptation finance has gained attention in recent years, but no definition of what it is has been agreed upon on. Often, adaptation money is rebranded development aid money. The degree of vulnerability should matter in the distribution of adaptation finance. However, the evidence presented suggests the opposite and adaptation projects often reflect donor preferences instead of local priorities. Fairness, i.e. who is responsible for climate change and should pay, would suggest that that the polluter pays, but there is no evidence for that in practice. Yet, an emphasis of the socio-economic drivers of vulnerability and therefore a more holistic understanding of the concept will help to establish who has to pay and implement adaptation measures. Adaptation should ideally take place at the local level but often adaptation finance and policies are made at the national and international levels. More combined approaches seem to be a promising venue to overcome this. Adaptation is more likely to succeed when it includes local ownership, integrates local and indigenous knowledge, and also considers adaptation barriers such as a lack of climate change awareness or misperceptions about climate change.

Access and allocation are clearly intertwined; it is often difficult to clearly distinguish between these two aspects, as well as the subcategories of basic needs; basic rights; and 
decision-making on the one hand, and resources, benefits, and opportunities; responsibilities; and risks on the other. It is thus not surprising that the literature does not discuss questions of fairness, justice, and equity under the rubric of "access and allocation", but uses different ways of systematically thinking about adaptation from a justice perspective. Scoville-Simonds et al. (2020), for example, propose the three categories of responsibility, vulnerability, and adaptation decision-making. The new ESG Science and Implementation Plan also replaced "access and allocation"; "access" may be subsumed under the new contextual condition "inequality", while "allocation" has found a new home as one of the research lenses "justice and allocation" (Earth System Governance Project 2018). While questions of justice, equity, and fairness are central to climate change adaptation, terminologies vary-which is unsurprising given the multi- and transdisciplinary nature of adaptation research. While we find that access and allocation offer a rather detailed way of approaching adaptation and adaptation research, this framework is not intuitive, as the concepts of access and allocation have no direct relationship to climate change or adaptation. This is probably why the notion of "climate justice" resonates more with both academic and policy debates.

Open Access This article is licensed under a Creative Commons Attribution 4.0 International License, which permits use, sharing, adaptation, distribution and reproduction in any medium or format, as long as you give appropriate credit to the original author(s) and the source, provide a link to the Creative Commons licence, and indicate if changes were made. The images or other third party material in this article are included in the article's Creative Commons licence, unless indicated otherwise in a credit line to the material. If material is not included in the article's Creative Commons licence and your intended use is not permitted by statutory regulation or exceeds the permitted use, you will need to obtain permission directly from the copyright holder. To view a copy of this licence, visit http://creativecommons.org/licenses/by/4.0/.

\section{References}

Adger, N., Arnella, N. W., \& Tompkins, E. L. (2005). Successful adaptation to climate change across scales. Global Environmental Change, 15, 77-86.

Ayeb-Karlsson, S., Smith, C. D., \& Kniveton, D. (2018). A discursive review of the textual use of 'trapped' in environmental migration studies: the conceptual birth and troubled teenage years of trapped populations. Ambio, 47, 557-573.

Ayers, J., \& Dodman, D. (2010). Climate change adaptation and development I: the state of the debate. Progress in Development Studies, 10(2), 161-168.

Ayers, J., \& Huq, S. (2009). Supporting adaptation to climate change: What role for official development assistance? Development Policy Review, 27(6), 675-692.

Barnett, J. (2008). The effect of aid on capacity to adapt to climate change: insights from Niue. Political Science, 60(1), 31-45. https://doi.org/10.1177/003231870806000104.

Barnett, J., \& Campbell, J. R. (2010). Climate change and small island states: power, knowledge and the south Pacific. London: Earthscan.

Barnett, J., \& O’Neill, S. (2010). Maladaptation. Global Environmental Change, 20(2), 211-213.

Barrett, S. (2014). Subnational climate justice? Adaptation finance distribution and climate vulnerability. World Development, 58, 130-142.

Barrett, S. (2015). Subnational adaptation finance allocation: comparing decentralized and devolved political institutions in Kenya. Global Environmental Politics, 15(3), 118-139.

Barrowman, H. M., \& Kumar, M. (2018). Conceptions of vulnerability in adaptation projects: A critical examination of the role of development aid agencies in Timor-Leste. Regional Environmental Change, 18, 2355-2367.

Bassett, T. J., \& Fogelman, C. (2013). Déjà Vu or something new? The adaptation concept in the climate change literature. Geoforum, 48, 42-53.

Bastos Lima, M. G., \& Gupta, J. (2013). The policy context of biofuels: A case of non-governance at the global level? Global Environmental Politics, 13(2), 46-64. 
Berchin, I. I., Valduga, I. B., Garcia, J., \& de Andrade Guerra, J. B. S. O. (2017). Climate change and forced migrations: An effort towards recognizing climate refugees. Geoforum, 84, 147-150.

Betzold, C. (2015). Adapting to climate change in small island developing states. Climatic Change, 133(3), 481-489.

Betzold, C., \& Flesken, A. (2014). Indigenous peoples in international environmental negotiations: Evidence from biodiversity and climate change. In T. Kaime (Ed.), International climate change law and policy: Cultural legitimacy in adaptation and mitigation (pp. 63-84). Abingdon: Routledge.

Betzold, C., \& Mohamed, I. (2017). Seawalls as a response to coastal erosion and flooding: A case study from Grande Comore, Comoros (West Indian Ocean). Regional Environmental Change, 17(4), 1077-1087.

Betzold, C., \& Weiler, F. (2016). Allocation of aid for adaptation to climate change: Do vulnerable countries receive more support?. International Environmental Agreements: Politics, Law and Economics.

Biermann, F., Betsill, M. M., Gupta, J., Kanie, N., Lebel, L., Liverman, D., et al. (2009). Earth System Governance: People, places and the planet. science and implementation plan of the Earth System Governance project. Bonn.

Biesbroek, R., Peters, B. G., \& Tosun, J. (2018). Public bureaucracy and climate change adaptation. Review of Policy Research, 35(6), 776-791. https://doi.org/10.1111/ropr.12316.

Bose, P., \& Lunstrum, E. (2014). Introduction: Environmentally induced displacement and forced migration. Refuge, 29(2), 5-10.

Buchner, B. K., Padraig, O., Wang, X., Carswell, C., Meattle, C., \& Mazza, F. (2017). Global landscape of climate finance 2017. Venice.

Buggy, L., \& McNamara, K. E. (2016). The need to reinterpret "community" for climate change adaptation: A case study of Pele Island, Vanuatu. Climate and Development, 8(3), 270-280.

Bulkeley, H., \& Newell, P. (2010). Governing climate change. London: Routledge.

Burton, I. (2004). Climate change and the adaptation deficit. In A. Fenech, D. MacIver, H. Auld, R. B. Rong, \& Y. Yin (Eds.), Climate change: Building the adaptive capacity: An international conference on adaptation science, management and policy options (pp. 25-33). Toronto: Meteorological Service of Canada, Environment Canada.

Campbell, J. R. (2014). Climate-change migration in the Pacific. Contemporary Pacific, 26(1), 1-29.

Capstick, S., Whitmarsh, L., Poortinga, W., Pidgeon, N., \& Upham, P. (2015). International trends in public perceptions of climate change over the past quarter century. Wiley Interdisciplinary Reviews-Climate Change, 6(1), 35-61.

Chasek, P., \& Rajaman, L. (2003). Steps toward enhanced parity: Negotiating capacity and strategies of developing countries. In I. Kaul (Ed.), Providing global public goods [electronic resource]: managing globalization (pp. 245-262). New York: Published for the United Nations Development Project [by] Oxford University Press.

Ciplet, D., Robert, J. T., \& Khan, M. (2013). The politics of international climate adaptation funding: Justice and divisions in the greenhouse. Global Environmental Politics, 13(1), 49-68.

Coolsaet, B., \& Pitseys, J. (2015). Fair and equitable negotiations? African influence and the international access and benefit-sharing regime. Global Environmental Politics, 15(2), 38-56.

Cooper, J. A. G., \& Pilkey, O. H. (Eds.). (2012). Pitfalls of shoreline stabilization: Selected case studies. Dordrecht: Springer.

Cui, L., \& Gui, H. (2015). Sharing the burden of financing the green climate fund in the post-Kyoto era. International Journal of Climate Change Strategies and Management, 7(2), 206-221.

Cui, L., \& Huang, Y. (2018). Exploring the schemes for green climate fund financing: International lessons. World Development, 101, 173-187.

Cvitanovic, C., Howden, M., Colvin, R. M., Norström, A., Meadow, A. M., \& Addison, P. F. E. (2019). Maximising the benefits of participatory climate adaptation research by understanding and managing the associated challenges and risks. Environmental Science \& Policy, 94, 20-31.

Dasgupta, D., \& Climate Finance Unit. (2015). Climate change finance, analysis of a recent OECD report: Some credible facts needed. Climate Change Finance Unit, Department of Economic Affairs, Ministry of Finance, Government of India. Retrieved December 8, 2016 from http://pibphoto.nic.in/docum ents/rlink/2015/nov/p2015112901.pdf.

de Sherbinin, A., Bukvic, A., Rohat, G., Gall, M., McCusker, B., Preston, B., et al. (2019). Climate vulnerability mapping: A systematic review and future prospects. Wiley Interdisciplinary Reviews: Climate Change, 10(5), e600. https://doi.org/10.1002/wcc.600.

Dellink, R., Elzen, M. D., Aiking, H., Bergsma, E., Berkhout, F., Dekker, T., et al. (2009). Sharing the burden of financing adaptation to climate change. Global Environmental Change, 19, 411-421. https:// doi.org/10.1016/j.gloenvcha.2009.07.009. 
Dilling, L., Prakash, A., Zommers, Z., Ahmad, F., Singh, N., de Wit, S., et al. (2019). Is adaptation success a flawed concept? Nature Climate Change, 9, 572-574.

Doria de França, M., Boyd, E., Tompkins, E. L., \& Adger, W. N. (2009). Using expert elicitation to define successful adaptation to climate change. Environmental Science \& Policy, 12, 810-819.

Dulal, H. B., Shah, K. U., \& Ahmad, N. (2009). Social equity considerations in the implementation of Caribbean climate change adaptation policies. Sustainability, 1, 363-383.

Dumaru, P. (2010). Community-based adaptation: Enhancing community adaptive capacity in Druadrua Island, Fiji. Wiley Interdisciplinary Reviews-Climate Change, 1(5), 751-763.

Duus-Otterström, G. (2015). Allocating climate adaptation finance: Examining three ethical arguments for recipient control. International Environmental Agreements. https://doi.org/10.1007/s1078 4-015-9288-3.

Eakin, H., Lemos, M. C., \& Nelson, D. R. (2014). Differentiating capacities as a means to sustainable climate change adaptation. Global Environmental Change, 27, 1-8.

Earth System Governance Project. (2018). Earth System Governance. Science and implementation plan of the Earth System Governance project. Utrecht.

Eisenack, K., Moser, S. C., Hoffmann, E., Klein, R. J. T., Oberlack, C., Pechan, A., et al. (2014). Explaining and overcoming barriers to climate change adaptation. Nature Climate Change, 4 , $867-872$.

Ensor, J. E., Abernethy, K. E., Hoddy, E. T., Aswani, S., Albert, S., Vaccaro, I., et al. (2018). Variation in perception of environmental change in nine Solomon Islands communities: implications for securing fairness in community-based adaptation. Regional Environmental Change, 18, 1131-1143.

Eriksen, S., \& Kelly, P. M. (2007). Developing credible vulnerability indicators for climate adaptation policy assessment. Mitigation and Adaptation Strategies for Global Change, 12, 495-524.

Eriksen, S., Nightingale, A. J., \& Eakin, H. (2015). Reframing adaptation: The political nature of climate change adaptation. Global Environmental Change, 35, 523-533.

Fankhauser, S., \& McDermott, T. K. J. (2014). Understanding the adaptation deficit: Why are poor countries more vulnerable to climate events than rich countries? Global Environmental Change, 27, 9-18.

Farbotko, C. (2019). Climate change displacement: Towards ontological security. In C. Klöck \& M. Fink (Eds.), Dealing with climate change on small islands: Toward effective and sustainable adaptation?. Göttingen: Göttingen University Press.

Farbotko, C., \& McMichael, C. (2019). Voluntary immobility and existential security in a changing climate in the Pacific. Asia Pacific Viewpoint, 60(2), 148-162.

Farbotko, C., McMichael, C., Dun, O., Ransan-Cooper, H., McNamara, K. E., \& Thornton, F. (2018). Transformative mobilities in the Pacific: Promoting adaptation and development in a changing climate. Asia and the Pacific Policy Studies, 5(3), 393-407.

Fenton, A., Gallagher, D., Wright, H., Huq, S., \& Nyandiga, C. (2014). Up-scaling finance for community-based adaptation. Climate and Development, 6(4), 388-397.

Flynn, M., Ford, J. D., Pearce, T., \& Harper, S. L. (2018). Participatory scenario planning and climate change impacts, adaptation and vulnerability research in the Arctic. Environmental Science \& Policy, 79(Supplement C), 45-53.

Ford, J. D., Cameron, L., Rubis, J., Maillet, M., Nakashima, D., Willox, A. C., et al. (2016). Including indigenous knowledge and experience in IPCC assessment reports. Nature Climate Change, 6(4), 349-353.

Foresight. (2011). Migration and global environmental change. London.

Füssel, H.-M. (2009). Review and quantitative analysis of indices of climate change exposure, adaptive capacity, sensitivity, and impacts.

Gharbaoui, D., \& Blocher, J. (2016). The reason land matters: Relocation as adaptation to climate change in Fiji Islands. In A. Milan, B. Schraven, K. Warner, \& N. Cascone (Eds.), Migration, risk management and climate change: Evidence and policy responses (pp. 149-173). Berlin: Springer.

Gibbs, M. T. (2016). Why is coastal retreat so hard to implement? Understanding the political risk of coastal adaptation pathways. Ocean and Coastal Management, 130, 107-114.

Goldstein, A., Turner, W. R., Gladstone, J., \& Hole, D. G. (2019). The private sector's climate change risk and adaptation blind spots. Nature Climate Change, 9(1), 18-25.

Granderson, A. A. (2014). Making sense of climate change risks and responses at the community level: A cultural-political lens. Climate Risk Management, 3, 55-64.

Grasso, M. (2010a). An ethical approach to climate adaptation finance. Global Environmental Change, $20,74-81$.

Grasso, M. (2010b). Justice in funding adaptation under the international climate change regime. Dordrecht: Springer.

Grecksch, K. (2013). Adaptive capacity and regional water governance in north-western Germany. Water Policy, 15(5), 794-815. https://doi.org/10.2166/wp.2013.124. 
Grecksch, K. (2015). Adaptive capacity and regional water governance in the Keiskamma River Catchment, Eastern Cape Province, South Africa. Water SA, 41(3), 359-368.

Grothmann, T., Grecksch, K., Winges, M., \& Siebenhüner, B. (2013). Assessing institutional capacities to adapt to climate change: Integrating psychological dimensions in the adaptive capacity wheel. Natural Hazards and Earth Systems Sciences, 13(12), 3369-3384. https://doi.org/10.5194/nhess -13-3369-2013.

Gupta, J., \& Lebel, L. (2010). Access and allocation in Earth System Governance: water and climate change compared. International Environmental Agreements: Politics, Law and Economics, 10(4), 377-395.

Habtezion, S., Adelekan, I., Aiyede, E., Biermann, F., Fubara, M., Gordon, C., et al. (2015). Earth System Governance in Africa: Knowledge and capacity needs. Current Opinion in Environmental Sustainability, 14, 198-205.

Hartzell-Nichols, L. (2011). Responsibility for meeting the costs of adaptation. WIREs Climate Change, 2, $687-700$.

Hayward, B. (2008). 'Nowhere far from the sea': Political challenges of coastal adaptation to climate change in New Zealand. Political Science, 60(1), 47-59.

Holland, B. (2017). Procedural justice in local climate adaptation: Political capabilities and transformational change. Environmental Politics, 26(3), 391-412. https://doi.org/10.1080/09644016.2017.1287625.

IOM. (2018). Global Migration Indicators 2018. Berlin: G. M. D. A. C. G. I. O. f. Migration.

IPCC. (2013). Annex II: Glossary. In T. Stocker, D. Qin, G.-K. Plattner, M. Tignor, S. Allen, J. Boschung, A. Nauels, Y. Xia, V. Bex, \& P. Midgley (Eds.), Climate change 2013: The physical science basis. Contribution of working group I to the fifth assessment report of the intergovernmental panel on climate change (pp. 1447-1466). Cambridge: Cambridge University Press.

IPCC. (2014). Glossary [Mach, K.J., S. Planton and C. von Stechow (eds.)]. Geneva, Switzerland.

IPCC. (2018). Global warming of $1.5^{\circ} \mathrm{C}$. An IPCC Special Report on the impacts of global warming of $1.5^{\circ} \mathrm{C}$ above pre-industrial levels and related global greenhouse gas emission pathways, in the context of strengthening the global response to the threat of climate change, sustainable development, and efforts to eradicate poverty Geneva.

Jinnah, S. (2014). Post-treaty politics: Secretariat influence in global environmental governance. Cambridge: The MIT Press.

Juhola, S. K. (2019). Responsibility for climate change adaptation. WIREs Climate Change, 10, e608.

Juhola, S. K., Glaas, E., Linnér, B.-O., \& Neset, T.-S. (2016). Redefining maladaptation. Environmental Science \& Policy, 55, 135-140.

Kanie, N., Nishimoto, H., Hijioka, Y., \& Kameyama, Y. (2010). Allocation and architecture in climate governance beyond Kyoto: Lessons from interdisciplinary research on target setting. International Environmental Agreements: Politics, Law \& Economics, 10(4), 299-315. https://doi.org/10.1007/s1078 4-010-9143-5.

Khan, M. (2015). Polluter-pays-principle: The cardinal instrument for addressing climate change. Laws, 4(3), 638-653.

Khan, M., \& Roberts, J. T. (2013). Adaptation and international climate policy. WIREs Climate Change, 4, 171-189.

Kinnvall, C., \& Mitzen, J. (2017). An introduction to the special issue: Ontological securities in world politics. Cooperation and Conflict, 52(1), 3-11.

Kirkby, P., Williams, C., \& Huq, S. (2018). Community-based adaptation (CBA): adding conceptual clarity to the approach, and establishing its principles and challenges. Climate and Development, 10(7), 577-589.

Klein, R. J. T. (2009). Identifying countries that are particularly vulnerable to the adverse effects of climate change: An academic or a political challenge? Carbon \& Climate Law Review, 3(3), 284-291.

Klepp, S., \& Chavez-Rodriguez, L. (2018). Governing climate change: The power of adaptation, discourses, policies, and practices. In S. Klepp \& L. Chavez-Rodriguez (Eds.), A critical approach to climate change adaptation: Discourses, policies, and practices (pp. 3-34). London: Routledge.

Klöck, C., \& Nunn, P. D. (2019). Adaptation to climate change in small island developing states: A systematic literature review of academic research. Journal of Environment and Development, 28(2), $196-218$.

Kuruppu, N., \& Willie, R. (2014). Barriers to reducing climate enhanced disaster risks in least developed country-small islands through anticipatory adaptation. Weather and Climate Extremes, 7, 72-83.

Lata, S., \& Nunn, P. D. (2012). Misperceptions of climate-change risk as barriers to climate-change adaptation: A case study from the Rewa Delta, Fiji. Climatic Change, 110, 169-186.

Magnan, A. (2014). Avoiding maladaptation to climate change: towards guiding principles. S.A.P.I.EN.S: Surveys and Perspectives Integrating Environment and Society, online. 
Marino, E., \& Lazrus, H. (2015). Migration or forced displacement?: The complex choices of climate change and disaster migrants in Shishmaref, Alaska and Nanumea, Tuvalu. Human Organization, 74(4), 341-350.

Massey, E., Huitema, D., Mees, H., Termeer, K., Storbjörk, S., Garrelts, H., et al. (2014). Handling adaptation policy choices in Sweden, Germany, the UK and the Netherlands. Journal of Water and Climate Change, 6(1), 9-24.

McEvoy, J., \& Wilder, M. (2012). Discourse and desalination: Potential impacts of proposed climate change adaptation interventions in the Arizona-Sonora border region. Global Environmental Change, 22, 353-363s.

McNamara, K. E., \& Combes, H. (2015). Planning for community relocations due to climate change in Fiji. International Journal of Disaster Risk Science, 6(3), 315-319.

McNamara, K. E., \& Jackson, G. (2019). Loss and damage: A review of the literature and directions for future research. WIREs Climate Change, 10(e564), 1-16.

Mechler, R., Bouwer, L. M., Schinko, T., Surminski, S., \& Linnerooth-Bayer, J. (Eds.). (2019). Loss and damage from climate change: Concepts, methods and policy options. Cham: Springer.

Mees, H. L. P., Driessen, P. P. J., Runhaar, H. A. C., \& Stamatelos, J. (2013). Who governs climate adaptation? Getting green roofs for stormwater retention off the ground. Journal of Environmental Planning and Management, 56(6), 802-825.

Mikulewicz, M. (2018). Politicizing vulnerability and adaptation: on the need to democratize local responses to climate impacts in developing countries. Climate and Development, 10(1), 18-34.

Mortreux, C., \& Barnett, J. (2009). Climate change, migration and adaptation in Funafuti, Tuvalu. Global Environmental Change, 19, 105-112.

Moss, R. H., Brenkert, A. L., \& Malone, E. L. (2001). Vulnerability to climate change: A quantitative approach. Prepared for the U.S. Department of Energy under contract DE-AC06-76RLO 1830. College Park, MD: Joint Global Change Research Institute, Battelle Pacific Northwest National Laboratory.

Nalau, J., Preston, B. L., \& Maloney, M. C. (2015). Is adaptation a local responsibility? Environmental Science \& Policy, 48, 89-98.

Narain, U., Margulis, S., \& Essam, T. (2011). Estimating costs of adaptation to climate change. Climate Policy, 11(3), 1001-1019.

Nawrotzki, R. J., \& DeWaard, J. (2018). Putting trapped populations into place: climate change and inter-district migration flows in Zambia. Regional Environmental Change, 18(2), 533-546.

Nielsen, J. Ø., \& Reenberg, A. (2010). Cultural barriers to climate change adaptation: A case study from Northern Burkina Faso. Global Environmental Change, 20, 142-152.

Nightingale, A. J. (2017). Power and politics in climate change adaptation efforts: Struggles over authority and recognition in the context of political instability. Geoforum, 84, 11-20.

Nunn, P. D. (2013). The end of the pacific? Effects of sea level rise on pacific island livelihoods. Singapore Journal of Tropical Geography, 34(2), 143-171.

Nunn, P. D., Aalbersberg, W., Lata, S., \& Gwilliam, M. (2014). Beyond the core: community governance for climate-change adaptation in peripheral parts of Pacific Island Countries. Regional Environmental Change, 14(1), 221-235.

Nunn, P. D., \& Kumar, R. (2019). Cashless adaptation to climate change: Unwelcome yet unavoidable? One Earth, 1(1), 31-34.

Oberlack, C. (2017). Diagnosing institutional barriers and opportunities for adaptation to climate change. Mitigation and Adaptation Strategies for Global Change, 22, 805-838.

Paavola, J., \& Adger, W. N. (2006). Fair adaptation to climate change. Ecological Economics, 56(4), 594-609.

Patt, A. G., \& Schröter, D. (2008). Perceptions of climate risk in Mozambique: Implications for the success of adaptation strategies. Global Environmental Change, 18, 458-467.

Pickering, J., Jotzo, F., \& Wood, P. J. (2015). Sharing the global climate finance effort fairly with limited coordination. Global Environmental Politics, 15(4), 39-62.

Piguet, E., Kaenzig, R., \& Guélat, J. (2018). The uneven geography of research on "environmental migration". Population and Environment, 39, 357-383.

Piguet, E., Pécoud, A., \& de Guchteneire, P. (2011). Migration and climate change: An overview. Refugee Survey Quarterly, 33(3), 1-23.

Reid, H., Alam, M., Berger, R., Cannon, T., Huq, S., \& Milligan, A. (2009). Community-based adaptation to climate change: an overview. Participatory Learning and Action, 60, 11-33.

Remling, E., \& Persson, А. (2015). Who is adaptation for? Vulnerability and adaptation benefits in proposals approved by the UNFCCC adaptation fund. Climate and Development, 7(1), 16-34.

Ringius, L., Torvanger, A., \& Underdal, A. (2002). Burden sharing and fairness principles in international climate policy. International Environmental Agreements: Politics, Law and Economics, 2(1), 1-22. 
Robert, J. T., \& Weikmans, R. (2017). Postface: Fragmentation, failing trust and enduring tensions over what counts as climate finance. International Environmental Agreements: Politics, Law and Economics, 17(1), 129-137.

Roberts, J. T., \& Parks, B. C. (2014). A climate of injustice: global inequality, north-south politics, and climate policy. Cambridge: MIT Press.

Robertsen, J., Francken, N., \& Molenaers, N. (2015). Determinants of the flow of bilateral adaptation-related climate change financing to sub-saharan African countries: LICOS Discussion Paper 373/2015. Catholic University Leuven.

Robinson, S.-A., \& Dornan, M. (2017). International financing for climate change adaptation in small island developing states. Regional Environmental Change, 17(4), 1103-1115.

Rotter, M., Hoffmann, E., Pechan, A., \& Stecker, R. (2016). Competing priorities: How actors and institutions influence adaptation of the German railway system. Climatic Change, 137, 609-623.

Schipper, E. L. F. (2006). Conceptual history of adaptation in the UNFCCC process. Review of European, Comparative and International Environmental Law, 15(1), 82-92.

Schipper, E. L. F., Ayers, J., Reid, H., Huq, S., \& Rahman, A. A. (2014). Community-based adaptation to climate change: Scaling it up. London: Routledge/Earthscan.

Schneider, T. (2014). Responsibility for private sector adaptation to climate change. Ecology \& Society, 19(2), 8.

Schroeder, H. (2014). Governing access and allocation in the Anthropocene. Global Environmental Change, 26, A1-A3. https://doi.org/10.1016/j.gloenvcha.2014.04.017.

Schroeder, H., Boykoff, M. T., \& Spiers, L. (2012). Equity and state representations in climate negotiations. Nature Climate Change, 2, 834-836.

Schroeder, H., \& Lovell, H. (2012). The role of non-nation-state actors and side events in the international climate negotiations. Climate Policy, 12, 23-37.

Scoville-Simonds, M., Jamali, H., \& Hufty, M. (2020). The hazards of mainstreaming: Climate change adaptation politics in three dimensions. World Development, 125, 1-10.

Sheller, M., \& León, Y. M. (2016). Uneven socio-ecologies of Hispaniola: Asymmetric capabilities for climate adaptation in Haiti and the Dominican Republic. Geoforum, 73, 32-46.

Siders, A. R. (2019). Adaptive capacity to climate change: A synthesis of concepts, methods, and findings in a fragmented field. Wiley Interdisciplinary Reviews: Climate Change. https://doi.org/10.1002/wcc.573.

Siebenhüner, B. (2018). Conflicts in transdisciplinary research: Reviewing literature and analysing a case of climate adaptation in Northwestern Germany. Ecological Economics, 154, 117-127.

Stadelmann, M., Michaelowa, A., Butzengeiger-Geyer, S., \& Köhler, M. (2014). Universal metrics to compare the effectiveness of climate change adaptation projects. In W. L. Filho (Ed.), Handbook of climate change adaptation. Berlin: Springer.

Stadelmann, M., Roberts, J. T., \& Michaelowa, A. (2011). New and additional to what? Assessing options for baselines to assess climate finance pledges. Climate and Development, 3(3), 175-192.

Stern, N. (2008). The economics of climate change. American Economic Review: Papers \& Proceedings, 98(2), $1-37$.

Thomas, K. A., \& Warner, B. P. (2019). Weaponizing vulnerability to climate change. Global Environmental Change, 57, 101928.

Underdal, A., \& Wei, T. (2015). Distributive fairness: A mutual recognition approach. Environmental Science \& Policy, 51, 35-44.

UNFCCC. (2009). Copenhagen accord: Contained in document FCCC/CP/2009/11/Add.1.

UNFCCC. (2015). Paris agreement: Document number FCCC/CP/2015/L.9/Rev.1.

United Nations. (1948). The Universal Declaration of Human Rights. Retrieved April 16, 2020 from https:// www.un.org/en/universal-declaration-human-rights/.

Warner, K. (2010). Global environmental change and migration: Governance challenges. Global Environmental Change, 20(3), 402-413.

Webber, S. (2015). Mobile adaptation and sticky experiments: Circulating best practices and lessons learned in climate change adaptation. Geographical Research, 53(1), 26-38. https://doi.org/10.1111/17455871.12102 .

Weber, E., Kissoon, P., \& Koto, C. W. (2019). Moving to dangerous places. In C. Klöck \& M. Fink (Eds.), Dealing with climate change on small islands: Toward effective and sustainable adaptation?. Göttingen: Göttingen University Press.

Weikmans, R. (2012). Le coût de l'adaptation aux changements climatiques dans les pays en développement. VertigO. La revue électronique en sciences de l'environnement, 12(1), 1-21.

Weikmans, R., \& Robert, J. T. (2017). The international climate finance accounting muddle: Is there hope on the horizon? Climate and Development. https://doi.org/10.1080/17565529.2017.1410087. 
Weiler, F., Klöck, C., \& Dornan, M. (2018). Vulnerability, good governance, or donor interests? The allocation of aid for climate change adaptation. World Development, 104, 65-77.

Winges, M., \& Grecksch, K. (2017). Resilience thinking-Is vagueness a blessing or curse in transdisciplinary projects? Experiences from a regional climate change adaptation project. In E. M. Trell, B. Restemeyer, M. Bakema, \& B. V. Hoven (Eds.), Governing for resilience in vulnerable places (pp. 57-76). Abingdon: Routledge.

WMO. (2019). WMO provisional statement on the state of the global climate in 2019. Geneva.

Woroniecki, S., Krüger, R., Rau, A.-L., Preuss, M. S., Baumgartner, N., Raggers, S., et al. (2019). The framing of power in climate change adaptation research. Wiley Interdisciplinary Reviews: Climate Change, 10, e617. https://doi.org/10.1002/wcc.617.

Zickgraf, C. (2018). Immobility. In R. McLeman \& F. Gemenne (Eds.), Routledge handbook of environmental displacement (pp. 71-84). Milton Park: Routledge.

Publisher's Note Springer Nature remains neutral with regard to jurisdictional claims in published maps and institutional affiliations. 